Marianna Czapnik

Warszawa

\title{
Druki proweniencji szwedzkiej w księgozbiorze warszawskiej książnicy uniwersyteckiej*
}

Wiek dziewiętnasty w znaczący sposób zmienił obraz kultury książki w Europie. Nasiliły się, zapoczątkowane w poprzednim stuleciach, zjawiska likwidacji, rozpraszania i przemieszczania księgozbiorów historycznych, spowodowane przez działania wojenne, zmiany granic państwowych, a także sekularyzację klasztorów i instytucji kościelnych. Utrata niepodległości przez Polskę a następnie walka o jej odzyskanie, miały wpływ nie tylko na sytuację polityczną kraju, ale znalazły swoje odbicie także w rozwoju kultury i nauki, a co za tym idzie historii książki i bibliotek. W szczególny sposób możemy to zaobserwować badając historyczny księgozbiór Biblioteki Uniwersyteckiej w Warszawie (dalej BUW).

Rozwój książnicy powstałej w 1817 r. został gwałtownie przerwany na skutek przegranego powstania listopadowego ${ }^{1}$. W ramach represji, władze carskie zamknęły Uniwersytet wraz z biblioteką. Zbiory biblioteczne i muzealne zostały potraktowane jako jeden z wojennych łupów, o czym pisał car Mikołaj I do namiestnika Imperium Rosyjskiego w Królestwie Polskim, Iwana Paskiewicza w 1832 r.: „Ponieważ zaś weszliśmy do Warszawy siłą oręża, więc i wszystkie podobne przedmioty stanowią

* Niniejsza publikacja to zmieniona i poszerzona wersja artykułu, który ukazał się w jęz. szwedzkim pod tyt. Böcker från andra sidan havet. Äldre tryckta skrifter med svensk proveniens $i$ universitetsbiblioteket $i$ Warszawa, tłum. Anna Wolodarski „Biblis”, Vintern 2012-2013, 60, sek 125, s. 2-25; fotografie większości opisanych znaków własnościowych zob. tamże oraz pod adresem http://www.kb.se/Dokument/ Biblis/Biblis60.Czapnik.pdf [I 2013].

1 Zarys historii biblioteki zob. M. Sipayłł, Wstęp, [w:] Katalog druków XV i XVI wieku $w$ zbiorach Biblioteki Uniwersyteckiej $w$ Warszawie, oprac. T. Komender, t. 1, Warszawa 1994, s. 13-52; M. Cubrzyńska-Leonarczyk, Polen [w:] Handbuch Deutscher Historischer Buchbestände in Europa, Bd. 6, bearb. M. Zacharska, J. Pirożyński, Hildesheim 1999, s. 61-71. 
nasze trofea. $Z$ łaski mogę im je później ofiarować, lecz należą one do nas"2. Większość zbiorów (ponad 90 tys. wol.) razem z archiwum, inwentarzami i katalogami wywieziono w latach 1832-34 do Imperatorskiej Biblioteki Publicznej w St. Petersburgu (obecnie Biblioteka Narodowa Rosji) ${ }^{3}$. W Warszawie pozostało jedynie ok. 40 tys. druków i ok. 300 rękopisów ${ }^{4}$. Do ocalałych resztek dołączono ok. 7 tys. tomów pozostałych po wywiezionej w tym samym czasie Bibliotece Warszawskiego Towarzystwa Przyjaciół Nauk ${ }^{5}$.

Na bazie obu księgozbiorów w 1840 r. władze rosyjskie utworzyły Bibliotekę Warszawskiego Okręgu Naukowego, podległą Ministerstwu Oświaty Cesarstwa Rosyjskiego ${ }^{6}$. Zbiory powoli powiększano, m.in. poprzez zakupy i dary. W latach $1840-42$ przysłano dublety z bibliotek St. Petersburga, określane jako „dary Najjaśniejszego Pana” [i.e. cara Mikołaja I]. Spisane w oddzielnym inwentarzu w 1845 r., obejmowały ok. 20 tys. tytułów książek w języku rosyjskim i językach zachodnioeuropejskich$^{7}$. Wśród nich znalazły się egzemplarze uprzednio wywiezione $\mathrm{z}$ terenów przyłączonych po rozbiorach do Rosji, w tym należące do Sapiehów z Kodnia i Radziwiłłów z Nieświeża, fragmenty biblioteki Załuskich i Towarzystwa Przyjaciół Nauk. W 1863 r. ponownie przysłano z St. Petersburga dublety, pochodzące ze zbiorów Imperatorskiej Biblioteki, Akademii Nauk, Ermitażu i Sztabu Generalnego ${ }^{8}$. Przybyło wówczas 17 tys. tomów, które włączono do księgozbioru, powołanej w $1862 \mathrm{r}$. Szkoły Głównej. Ponad połowę tego wpływu stanowiły wydawnictwa wydane do 1801 r., głównie w językach łacińskim, niemieckim i francuskim, nieco mniej w polskim i rosyjskim. Znalazły się wśród nich dzieła z nauk historycznych, przyrodniczych, geograficznych, matema-

${ }^{2}$ Cyt. za J. Kucharzewski, Epoka paskiewiczowska, losy oświaty, Warszawa - Kraków 1914, s. 86; zob. też tamże, s. 60-86; H. Kozerska, Warszawska Biblioteka Uniwersytecka $w$ latach 1832-1871, Warszawa 1967, s. 1-3; Z. Strzyżewska, Konfiskaty warszawskich zbiorów publicznych po powstaniu listopadowym. Biblioteka Uniwersytetu Warszawskiego i Warszawskie Towarzystwo Przyjaciót Nauk. Materiaty i dokumenty $z$ archiwów rosyjskich, Warszawa 2000, s. 9-14, 21-69.

${ }^{3}$ H. Kozerska, Straty w zbiorze rękopisów w czasie I i II wojny światowej, Warszawa 1960, s. 11; Z. Strzyżewska, Konfiskaty zbiorów Warszawskiego Towarzystwa Przyjaciół Nauk po powstaniu listopadowym, ,Zeszyty Staszicowskie”, 1998, 1, s. 168.

${ }^{4}$ H. Kozerska, Warszawska Biblioteka... s. 3.

${ }^{5}$ Z. Strzyżewska, Konfiskaty... s. 71-86.

${ }^{6}$ H. Kozerska, Warszawska Biblioteka... s. 7-14.

${ }^{7}$ BUW, Archiwum (dalej cyt. Arch. BUW) sygn. I,20, Wykaz książek w obcych językach z daru Najjasniejszego Pana w 1840 roku nadesłanych; Tamże, Arch. BUW, sygn. I/22 Wykaz książek w obcych językach z daru Najjaśniejszego Pana w 1842 roku nadesłanych.; zob. też J. Kucharzewski, Epoka paskiewiczowska, s. 95-96, wg Kucharzewskiego było 21669 tomów, por. s. 96; H. Kozerska, Warszawska Biblioteka... s. 14-15.

${ }^{8}$ H. Kozerska, Warszawska Biblioteka... s. 38-39, 64-65. 
tyczno-fizycznych i prawniczych. Niewielką partię książek (3470 dzieł w 6389 wol.), pochodzących ze zbiorów Sztabu Generalnego, Cesarskiej Akademii Nauk i Johana Petera Suchtelena, przed wysłaniem z St. Petersburga spisał i skatalogował pracownik Biblioteki Cesarskiej, Antoni Iwanowski ${ }^{9}$.

$\mathrm{W}$ trakcie badań proweniencyjnych prowadzonych w BUW, zwłaszcza w zespole druków XVII-XVIII stulecia, okazało się, że sporo z nich pochodzi z rozproszonych kolekcji szwedzkich ${ }^{10}$. Te właśnie, dotychczas ujawnione egzemplarze (53 dzieła w 49 wol.) będą przedmiotem dokładniejszej analizy w niniejszej pracy. Zespół ten jest interesujący również pod względem bibliograficznym, zawiera bowiem dzieła w języku szwedzkim, publikowane w Sztokholmie, Kopenhadze i Uppsali, niezbyt licznie reprezentowane w zbiorach książnicy uniwersyteckiej. Wśród autorów pochodzących z krajów skandynawskich są historycy: Peter Petrejus (ok. 1570-1622), Samuel Kempenskiöld (1599-1670) i Julius Eric Biörner (1696-1750); prawnik i filolog Johann Scheffer (1621-1679); kaznodzieja i pisarz Simon Isogaeus (1643-1709); biskupi - Hans Nielsen Strelow (1587-1656) i Johannes Elai Terserus (1605-1678); botanik, lingwista i teolog Olaf Celsius st. (1670-1756); sławny uczony i botanik Karol Linneusz (1707-1778); etymolog Carl Alexander Clerck (1709-1765), a także polityk i generał w armii pruskiej, Johan Ludvig von Hordt (1719-1798).

Najliczniejszy zbiór druków proweniencji skandynawskiej zawiera księgozbiór należący uprzednio do Sztabu Generalnego armii rosyjskiej. Informacje dotyczące tej jednej z najcenniejszych bibliotek wojskowych w Rosji są nader skape ${ }^{11}$. Powstała $\mathrm{z}$ inicjatywy szefa Sztabu Generalnego, księcia P. M. Wołkońskiego, który w 1811 r. zwrócił się do cara Aleksandra I z prośbą o utworzenie przy sztabie specjalnego księgozbioru przeznaczonego dla oficerów, w celu pogłębiania ich wiedzy ogólnej

${ }^{9}$ Arch. BUW, sygn. I/83 Spis dzieł (3470) wysłanych do Warszawy dla Szkoły Głównej z Bibliotek Petersburskich... w liczbie 6538 tomów, otrzymanych i uporządkowanych, a także skatalogowanych staraniem Antoniego Iwanowskiego Bibliotekarza Cesarskiej Biblioteki Publicznej w Petersburgu dn. 8/10 lipca 1863 roku; H. Kozerska, Warszawska Biblioteka..., s. 38.

${ }^{10}$ Badania proweniencyjne w BUW zapoczątkowała w 1959 r. dr Maria Sipayłło, zob. M. Cubrzyńska-Leonarczyk, Badacz i znawca księgozbiorów historycznych - Maria Sipayłto, [w:] W kregu nauki i bibliotek. Bibliotekarze polscy we wspomnieniach, Warszawa, 1993, t. 3, s. 52-62. W 2007 r. w Gabinecie Starych Druków BUW rozpoczęto rejestrację właścicieli druków XVII-XVIII w., z sygnatur topograficznych dotychczas nieprzebadanych lub tylko częściowo ujętych w kartotekach. Dotychczas badaniami objęto ok. 35\% kolekcji. Większość egzemplarzy uwzględnionych w niniejszym opracowaniu pochodzi z tego zasobu.

${ }_{11}$ Biblioteka General'nogo štaba russkoj armii 1811-1911 - http://www.rsl.ru/ru/s7/ s381/2008/s5033322/ [ I 2013]. 
i zawodowej. Fundamentem zbiorów były prywatne kolekcje oficerów, w tym księcia Wołkońskiego, Łobanow-Rostowskiego, rodziny Czartoryskich oraz generałów, Liprandi i Suchtelena. W bibliotece znajdowały się cenne i rzadkie druki z różnych dziedzin wiedzy, wydane w znanych drukarniach zachodnioeuropejskich. Zbiory były rozdzielane już w XIX w., oprócz wspomnianego wyżej daru dla Biblioteki Głównej w Warszawie, w 1888 r. do biblioteki uniwersyteckiej w Moskwie przekazano 274 tomy. Książki z biblioteki Sztabu Generalnego oznaczone są ekslibrisem graficznym, uzupełnionym informacją o sygnaturze topograficznej $^{12}$, a także zieloną skórzaną nalepką naklejaną na grzbiecie. W jaki sposób druki o proweniencji szwedzkiej znalazły się w tym księgozbiorze trudno obecnie wyjaśnić. Wiadomo natomiast, że w armii rosyjskiej służyło wielu oficerów szwedzkich, którzy mogli podarować swoje zbiory, inne napłynęły zapewne poprzez wymianę między oficerami lub też mogły być zdobyte $\mathrm{w}$ wyniku prowadzonych w Skandynawii działaniach wojennych.

Drugi pod względem ilości zespół dzieł należących uprzednio do właścicieli pochodzenia szwedzkiego, odnotowano dotychczas w księgozbiorze oficera i dyplomaty, Jana Pietera van Suchtelena, który w rosyjskiej historiografii znany jest jako Petr Kornilovič Suchtelen (1751-1836). Suchtelen urodził się i zdobył wykształcenie w Holandii ${ }^{13}$. W 1783 r. przeszedł na służbę w armii rosyjskiej, w stopniu inżyniera pułkownika. Za zasługi wojenne otrzymał najpierw tytuł barona Wielkiego Księstwa Finlandii, a w 1822 r. tytuł księcia. W 1812 r. zamieszkał na stałe w Sztokholmie jako nadzwyczajny delegat cara rosyjskiego na dworze króla Szwecji.

Pierwsze wzmianki o bibliotece Suchtelena pochodzą z początkowych lat panowania cara Aleksandra I (1801-1825), który przeznaczył Zamek Michajłowski w St. Petersburgu na siedziby dla oficerów ze swojej świty. Suchtelen otrzymał tam obszerne mieszkanie, dokąd mógł przenieść również swoje zbiory, udostępniane odwiedzającym go gościom i oficerom $^{14}$. Rosyjski generał zdołał zgromadzić dużą kolekcję inkunabułów i cennych druków, często w luksusowych oprawach. Ponadto, zbierał rękopisy, autografy znanych osób, ryciny, mapy, atlasy, monety, medale, itp. Oznaczał książki ekslibrisem heraldycznym wykonanym techni-

${ }^{12}$ E. S. Kašutina, N. G. Saprykina, Ekslibris v sobranii Naučnoj biblioteki Moskovskogo universiteta. Al'bom-katalog, Moskva 1985, tabl. 35.

${ }^{13}$ A. M. Pančenko, General, diplomat, bibliofil. Iz istorii knižnogo sobranija P. K. Suchtelena, „Bibliosfera”, 4, 2006: http://www.spsl.nsc.ru/win/Bibliosfera/panchenko\%20 4-2006.pdf [ I 2013], s. 3-9.

${ }^{14}$ Tamże, s. 4-5. 
ką miedziorytu, sporządzonym zapewne w latach trzydziestych XIX w. Znajdują się na nim: pięciopolowa tarcza herbowa pod korona, podtrzymywaną przez dwa lwy, pod tarczą cesarski order św. Andrzeja Apostoła, który nadawano osobom w randze co najmniej generała lejtnanta. Wokół umieszczono napis „Bibliotheca Suchtelen.” oraz dewize „Aequa mente". Znamy dwa warianty tego znaku, które zasadniczo różnią się jedynie wymiarami: $98 \times 100 \mathrm{~mm}^{15}$ i $60 \times 54 \mathrm{~mm}$. Ponadto, na kartach ksiag spotykamy pieczęcie w trzech odmianach, heraldyczna - z napisem w otoku „Bibliothecae Suchtelen.” oraz dwie napisowe: „Bibliotheca Suchtelen.” i ,Suchtelen”. Zbiory Suchtelena były dobrze znane w środowisku uczonych i kolekcjonerów szwedzkich. W Sztokholmie, generał prowadził dom otwarty, w którym spotykali się dyplomaci, politycy, uczeni i literaci. Nierzadko obdarowywał cennymi książkami lub numizmatami Królewską Akademię Nauk lub uniwersytet w Uppsali. Sam otrzymywał wiele darów oraz prowadził wymianę z innymi zbieraczami, m.in. z Larsem von Engeström (1751-1826). Po śmierci Suchtelena, w 1836 r. biblioteka została odkupiona od spadkobierców, a następnie przewieziona do St. Petersburga i umieszczona w budynku Sztabu Generalnego armii rosyjskiej ${ }^{16}$. W katalogach było wówczas zarejestrowanych 41 tys. druków, w tym 900 inkunabułów, ok. 4 tys. edycji rzadkich i cennych oraz ok. 1 tys. wydań ilustrowanych. Ponadto, wśród nieskatalogowanych obiektów, znajdowały się rękopisy i autografy, dysertacje akademickie, mapy i numizmaty. Całość oszacowano na ok. 70 tys. jednostek. Zbiory te następne rozdzielono pomiędzy biblioteki w St. Petersburgu i Moskwie $^{17}$. W siedzibie Sztabu Generalnego pozostało jedynie ok. 13 tys. woluminów. Cesarska Biblioteka Publiczna otrzymała ok. 27 tys. książek naukowych $\mathrm{z}$ różnych dziedzin wiedzy oraz rękopisy i autografy, pozostałe obiekty przekazano do Ermitażu oraz innych instytucji naukowych i muzealnych w Rosji. Obecnie zbiory biblioteczne i muzealne Suchtelena są rozproszone w wielu bibliotekach i muzeach na świecie, w Rosji, Szwecji, Finlandii, Holandii, USA i w Polsce.

Poza wyżej opisanymi księgozbiorami Suchtelena i Sztabu Generalnego, pewna partia książek z proweniencjami szwedzkimi znalazła się w zbiorach BUW drogą nieznaną lub razem z fragmentami innych rozproszonych kolekcji prywatnych.

Wśród zarejestrowanych dotychczas właścicieli ksiąg pochodzących bądź związanych ze Szwecja, notujemy osoby należące do różnych grup

${ }^{15}$ E. S. Kašutina, Ekslibris..., il. 25.

${ }^{16}$ A. M. Pančenko, General, diplomat..., s. 6.

${ }^{17}$ Tamże, s. 7. 
społecznych. Możemy wyróżnić wywodzących się z arystokracji wyższych urzędników państwowych, dyplomatów i oficerów, duchownych, uczonych i pisarzy, związanych przede wszystkim z uniwersytetem w Uppsali, a także studentów i absolwentów tej uczelni. Ilościowo dominuja osoby gromadzące książki wydane w XVII i XVIII stuleciu. W prezentowanym zespole przeważają publikacje w języku francuskim i po łacinie, przy czym język szwedzki jest również reprezentowany w znaczącej ilości. Natomiast tematycznie dominuja prace dotyczące historii krajów nordyckich, dziejów współczesnych oraz nauk matematyczno-przyrodniczych.

Przegląd najciekawszych dzieł i zapisów proweniencyjnych rozpoczniemy od najstarszej w tym wykazie edycji, niemieckiego tłumaczenia żywotów sławnych mężów Plutarcha, wydanych w 1547 r. (poz. w wyk. 40). Właścicielem tego egzemplarza był polityk i dyplomata w służbie króla Jana III Wazy, Mauritz Svantesson Sture (1552-1592) książę Västerik i Stegeholm oraz jego syn Svante (1587-1616) ${ }^{18}$.

Drugie wydanie traktatu Mikołaja Kopernika De revolutionibus orbium coelestium libri VI (Bazylea 1566, poz. w wyk. 28), landgraf Hessen-Kassel Maurycy (1572-1632), zwany przez współczesnych ,uczonym”, podarował w 1594 r. swojemu nadwornemu matematykowi Nilsowi Chesnecopherusowi (1574-1622) ${ }^{19}$. Chesnecopherus studiował w Helmstedt, Wittenberdze i w Marburgu, gdzie w 1593 r. uzyskał stopień magistra. Po studiach pracował na dworze landgrafa oraz wykładał na uniwersytecie w Marburgu. Po kilku latach powrócił do Szwecji aby objąć urząd kanclerza na dworze Karola IX. W książce znajdujemy liczne komentarze do tekstu rozprawy pisane ręką szwedzkiego matematyka, a także pierwszego niezidentyfikowanego właściciela.

Jedną ze znaczniejszych bibliotek w XVII w. zgromadził długoletni kanclerz królestwa szwedzkiego i faworyt królowej Krystyny, Magnus Gabriel De la Gardie (1622-1686). Miał on w swoich zbiorach m.in. słynną Srebrną Biblię (Codex Argenteus), którą podarował w 1669 r. uniwersytetowi w Uppsali ${ }^{20}$. Po jego śmierci, większość zbiorów - ok. 4700 książek i rękopisów, a wśród nich rękopisy z biblioteki Zygmunta III Wazy oraz pewną ilość książek wywiezionych przez Szwedów z War-

\footnotetext{
${ }^{18}$ Nie można też wykluczyć, że pierwszym właścicielem był ojciec Mauritsa, Svante Sture z Hörningsholm (1517-1567), baron i książę, gubernator generalny Inflant i Rewala od $1562 \mathrm{r}$.

19 O. Gingerich, An Annotated Census of Copernicus De Revolutionibus (Nuremberg, 1543 and Basel, 1566), Leiden - Boston - Köln 2002, s. 174-177.

${ }^{20}$ Zob. http://www.ub.uu.se/en/Collections/Manuscript-Collections/Silver-Bible [I 2013].
} 
szawy w poł. XVII w. - otrzymała uppsalska Carolina Rediviva ${ }^{21}$. De la Gardie oznaczał woluminy lakową pieczęcią herbową z inicjałami MG/ DLGC/ILEA. W zbiorach warszawskich z jego kolekcji posiadamy gramatykę grecka, wydaną w słynnej antwerpskiej oficynie Krzysztofa Plantyna w 1576 r. (poz. w wyk. 35).

Dwa woluminy opatrzone są notami własnościowymi Johana Rosenhane (1642-1710) - hiszpańskojęzyczna historia Chin autorstwa Juana Gonzaleza de Mendoza (Frankfurt n. M. 1589; poz. w wyk. 22) oraz jeden $\mathrm{z}$ tomów Elegantiares praestantium virorun satyrae (Lejda 1655, poz. w wyk. 18). Johan Rosenhane, urzędnik królewski, dyplomata i ambasador Szwecji w Berlinie, był najmłodszym synem znanego w Polsce Scheringa (1609-1663), który „zasłynął” złupieniem księgozbiorów jezuickich w Toruniu i Bydgoszczy latem 1656 r. ${ }^{22}$ Schering Rosenhane zgromadził jeden z największych księgozbiorów prywatnych w ówczesnej Szwecji, zasobny także w cenne polonika. Po śmierci żony w 1672 r., księgozbiór odziedziczony przez dzieci uległ rozproszeniu.

Wielu właścicieli, w tym kilku pochodzenia szwedzkiego, pozostawiło swoje adnotacje na kartach Arithmeticae libri duo, francuskiego humanisty i matematyka Petrusa Ramusa (Frankfurt n. M. 1599, poz. w wyk. 43). Pierwszym właścicielem, już w 1599 r. był student uniwersytetu w Lipsku (1598) i Jenie (1599), poeta laureatus Daniel Tordsson Hjort Fabrivillensis (ok. 1575-1615). Następny posesor, opiekun w 1622 r. podczas podróży edukacyjnej do Holandii synów kanclerza uniwersytetu w Uppsali Johana Skytte (1577-1645), Petrus Doberus z Västerås (Arosio) w 1634 r. podarował to dzieło Abrahamowi Kempe (1595-1643/44). Kempe, student uniwersytetu w Uppsali (1634), sekretarz szwedzkiego kolegium królewskiego, pisarz i edytor, znany jest przede wszystkim z pierwszego thumaczenia psałterza na język szwedzki. Kolejny odnotowany właściciel, Etter Karl Antonović, sekretarz gubernialny, członek Cesarskiej Akademii Nauk w St. Petersburgu, w 1822 r. przekazał to dzieło do Cesarskiej Biblioteki Publicznejej skąd dotarło do BUW.

Przegląd publikacji wydanych w następnych stuleciach rozpoczniemy informacją o egzemplarzu z kolekcji Krystyny z dynastii Wazów (1626-1689), królowej Szwecji w latach 1644-1654. Niewielkich rozmiarów tomik, za-

${ }^{21} \mathrm{Cz}$. Pilichowski, $Z$ dziejów szwedzkich zaborów bibliotek $i$ archiwów polskich w XVII i XVIII w., Gdańsk 1960, s. 14, 16.

22 A. Birkenmajer, Ksiażka O. Waldego o szwedzkich zdobyczach bibliotecznych, „Exlibris”, 5:1924, s. 72-73; Cz. Pilichowski, Z dziejów..., s. 14; T. Borawska, Dawne ksiażki warmińskie w zbiorach bibliotek europejskich, [w:] W kręgu stanowych i kulturalnych przeobrażeń Europy Pótnocnej w XIV-XVIII w., Toruń 1988, s. 181.

${ }^{23}$ Obecnie Biblioteka Narodowa Rosji w St. Petersburgu. 
wierający jedną z bardziej znanych prac niemieckiego historyka Eberharda Wassenberga Der Teutsche Florus (Gdańsk 1643, poz. w wyk. 53), dedykowaną królowej Cecylii Renacie, żonie króla Władysława IV Wazy, otrzymał skromną oprawę w pergamin, ozdobiony jedynie cienką złoconą ramką wykonaną przy pomocy strychulca. Na górnej okładzinie odbito superekslibris: w polu sercowym herb Wazów Snopek oraz ułożone naprzemiennie godła Szwecji i Gotlandii pod koroną królewska, powyżej której wytłoczono inicjały „C[ristina] R[egina] S[veciae]”. Królowa Krystyna, jak wiadomo, była właścicielką dużego księgozbioru, zakupionego po jej śmierci do zbiorów watykańskich przez papieża Aleksandra VIII. Omawiany wolumin dotarł do książnicy uniwersyteckiej w Warszawie drogą nieznaną.

Niewatpliwie, jedną z cenniejszych ksiagg w zbiorach BUW jest Biblia w języku szwedzkim wydana w Lejdzie w 1635 r. (poz. w wyk. 4), dedykowana przez drukarza Jacoba Marci królowej Krystynie oraz wysokim urzędnikom państwowym, w tym trzem z rodu Oxenstierna. Zdobi ja sztychowana karta tytułowa ze scenami ze Starego i Nowego Testamentu oraz tablice $\mathrm{z}$ herbami osób, którym Biblię zadedykowano. Równie interesujący jest zapis własnościowy ręką Johana Oxenstierny (1611-1657). Był on synem wymienionego w liście dedykacyjnym Axela, kanclerza Szwecji, męża stanu i najbliższego współpracownika króla Gustawa II Adolfa. Johan urodził się w Sztokholmie w 1611 r., ukończył studia w Uppsali w 1631 r., a następnie podróżował w celach edukacyjnych po Europie. Potem występuje jako polityk - ze strony dworu szwedzkiego podpisał ugodę szwedzko-polską w Sztumskiej Wsi w 1635 r. Biblię oprawiono $\mathrm{w}$ wiśniową skórę typu maroquin, zdobioną w stylu á la èventail. Elegancji dodaja jej też złocone obcięcia kart, puncowane we wzory roślinne. Oprawa ta, obecnie już nieco wytarta, ma niewielkie ślady opalenia, prawdopodobnie przez świecę.

Z biblioteki młodszego brata Johana, Erika Oxenstierny (1624-1656), kanclerza Szwecji i gubernatora Prus, pochodzi dzieło Historia universale dell'origine guerre et imperio de Turchi Francesca Sansovino (Wenecja 1654, poz. w wyk. 47). Właściciel tego tomu niechlubnie zapisał się w dziejach Polski, dokonując rabunku księgozbiorów i archiwów Warszawy w czasie wojny polsko-szwedzkiej w 1655 r. Zgromadził ogromny księgozbiór, zawierający wiele cennych poloników, sprzedany przez spadkobierców na aukcji w 1732 r., rozproszony obecnie w wielu bibliotekach w Szwecji i poza jej granicami ${ }^{24}$. Omawiany wolumin dotarł do Warszawy w 1863 r. z częścią zbiorów Sztabu Generalnego armii rosyjskiej.

\footnotetext{
${ }^{24}$ A. Birkenmajer, Ksiażka O. Waldego..., s. 69-70, 73.
} 
Książki i rękopisy zabrane z terenów Polski w czasie III wojny północnej (1700-1721) miał w swojej kolekcji Olof Hermelin (1658-1709), student w Uppsali, historyk, profesor na uniwersytecie w Tartu, sekretarz stanu i dyplomata. Uczestniczył on w grabieży archiwum i biblioteki biskupa warmińskiego w Heilsbergu (dzisiaj Lidzbark Warmiński) w latach 1703-170425. Z kolei, z jego zbiorów mamy historię wojen duńskich Johanna Heinricha Boeclera (Sztokholm 1676, poz. w wyk. 8). Prosta oprawę w gładzony pergamin obciagnięty na grubej tekturze wykonano w Szwecji, bowiem do jej wzmocnienia użyto makulatury zadrukowanej w języku szwedzkim. Oprawę zdobią jedynie obcięcia kart nakrapiane czerwoną farbą.

Posiadaczem znacznego księgozbioru, zawierającego druki ze wszystkich dziedzin wiedzy, był Carl Gustaf Tessin (1695-1770), jeden z ważniejszych polityków szwedzkich w XVIII stuleciu. Był on wieloletnim mecenasem Karola Linneusza, który opracował katalog roślin, zwierząt i minerałów z kolekcji swojego patrona, wydany pod tytułem Museum Tessinianum w 1753 r. Po śmierci właściciela, księgozbiór przeszedł na własność księcia Gustawa III (1746-1792), późniejszego króla Szwecji (1771-1796), a dzieła sztuki zasiliły zbiory Muzeum Narodowego. W bibliotece warszawskiej dotychczas zidentyfikowano dwa dzieła, czyli bogato ilustrowane, sześciotomowe Memoires pour servir a l'histoire des insects, wydane w Paryżu w latach 1734-1742 (poz. w wyk. 44) oraz jeden $\mathrm{z}$ woluminów historii anatomii Thomasa Bartholina (Sztokholm 1657, poz. w wyk. 3). Warto tu nadmienić, że tomy 5-6 tej samej edycji z biblioteki Tessina, nadal znajdują się w Sztokholmie, obecnie w zbiorach Biblioteki Królewskiej ${ }^{26}$.

Zapewne duży księgozbiór posiadał także Claes Julius Ekeblad (17421808), pochodzacy $\mathrm{z}$ rodziny arystokratycznej. Po studiach w Uppsali w 1757 r. rozpoczął karierę wojskowa, najpierw w rodzinnym kraju, a następnie we Francji. Po powrocie do Szwecji objął funkcję gubernatora, m.in. Uppsali. Z jego zbiorów przechowujemy w Warszawie traktat hiszpańskiego podróżnika i ambasadora w Persji, Garcia de Silva Figueroa w thumaczeniu na język francuski, omawiający historię Persji i stosunki hiszpańsko-perskie w czasie pobytu autora w tym kraju (Paryż 1657, poz. w wyk. 20). Wolumin oprawiony $\mathrm{w}$ pergamin, oznaczony jest autografem właściciela oraz mała pieczęcią heraldyczną z motywem dębowego liścia pod koroną oraz dewizą: „ära och trohet” (godność i wierność), odbitą w czarnym laku.

${ }^{25}$ Tamże, s. 74; Cz. Pilichowski, Z dziejów..., s. 18-19; T. Borawska, Dawne ksiqżki warmińskie..., s. 182.

${ }^{26}$ Zob. LIBRIS - http://libris.kb.se/bib/2495533?vw=full [I 2013]. 
Gubernatorem Åbo (Turku) i Uppsali był Johan Georg Lillienberg (1713-1798), polityk, dyplomata i członek parlamentu. Po ukończeniu studiów w Lund w 1731 r. pojechał z misją dyplomatyczną do Konstantynopola i Turcji. W swojej bibliotece miał m.in. jedną z ważniejszych rozpraw historycznych w dorobku francuskiego pisarza Henri'ego de Boulainvilliers, Etat de la France (Londyn 1737, poz. w wyk. 10), opisująca dzieje monarchii absolutnej we Francji w XVIII w.

Do grona polityków zaliczymy także Erika Bergstedta (1760-1829), dyplomatę, sekretarza poselstwa, a następnie radcę stanu w ambasadzie szwedzkiej w Paryżu. W przetłumaczonej przez siebie pracy Resa till Propontiden och Svarta Havet, (Stockholm 1802-1805) zamieścił wspomnienia z podróży do Egiptu, Konstantynopola i Grecji w latach 17941797. W BUW znajduje się jedna książka z jego autografem, dotycząca historii wojen w Hiszpanii i Portugalii za czasów króla Filipa V (poz. w wyk. 2).

Następny polityk reprezentowany w naszych zbiorach to Carl Friedrich Eckleff (1723-1786), sekretarz wydziału spraw zagranicznych i doradca rządu szwedzkiego. Był jednym z założycieli pierwszej loży masońskiej „Scottish Lodge of St. Andrew” w Sztokholmie w 1756 r. Zgromadził liczny i cenny księgozbiór, który oznaczał ekslibrisem heraldycznym w polu herbowym trzy liście dębowe pod korona. W 1760 r. zakupił część słynnej biblioteki Rosenhanów, w której znajdowały się fragmenty polskich księgozbiorów wywiezionych w czasie wojny polsko-szwedzkiej w 1655 roku $^{27}$. Zbiory Eckleffa były dwukrotnie wystawiane na aukcjach, w 1769 i 1786 r. Do Polski, poprzez bibliotekę Sztabu Generalnego, trafił druk Williama Camdena, Rerum Anglicarum et Hibernicarum annales, wydany w słynnej oficynie Elzewirów w 1637 r. (poz. w wyk.11). Eckleff był trzecim odnotowanym właścicielem tego tomu. Pierwszy z nich, ukryty pod inicjałami S.R., zapewne oznacza wspomnianego już wyżej Scheringa Rosenhane. Następnie, jego syn Johan podpisał się w 1673 r. W bibliotece Rosenhanów zgromadzono dużo druków wydanych w oficynie Elzewirów ${ }^{28}$.

Matthias von Benzelstierna (1713-1791), absolwent uniwersytetu w Lund i wieloletni przyjaciel Karola Linneusza, zgromadził jedną z największych i najcenniejszych prywatnych bibliotek w ówczesnej Szwecji.

${ }^{27}$ O. Walde, Storhetstidens litterära krigsbyten, en kulturhistorisk bibliografisk studie, II, Uppsala 1920, s. 161-162.

28 Zob. P. O. Samuelsson, Inkunabel och 1500-talstryck (,,Vaggtryck och koltålderstryck”) i Roggenbiblioteket, Strengensiae 2009, s. 57, 111 - http://www.nattvakt.com/kataloger/Katalog1500.doc [I 2013]. 
Interesował się historią i naukami przyrodniczymi, należał do Królewskiej Akademii Nauk w Sztokholmie i Królewskiego Towarzystwa Naukowego w Uppsali. Po 1759 roku, za zasługi w służbie państwu, odznaczono go Orderem Gwiazdy Polarnej. Księgozbiór oraz zbiór rękopisów i monet, odziedziczył, wspomniany wyżej, siostrzeniec Lars von Engeström. W 1864 r. kolekcję znaną już pod nazwą „Engeströmska”, przekazano do Biblioteki Królewskiej w Sztokholmie. Benzelstierna oznaczał swoje książki ekslibrisem heraldycznym z dewizą „Plus esse quam videri”, wykonanym techniką miedziorytu. W BUW mamy dwa woluminy z jego kolekcji, opatrzone ekslibrisem sporządzonym po 1759 r., bowiem kartusz herbowy otoczony jest łańcuchem z insygniami Wielkiego Krzyża Orderu Gwiazdy Polarnej. Na bliższą uwagę zasługuje niezwykle ciekawy klocek introligatorski z księgozbioru Benzelstierny, zawierający cztery niewielkiej objętości dzieła autorów związanych z uniwersytetem w Uppsali: Prodromus tractatum de geographia Scandinaviae Erica Juliusa Biörnera (Sztokholm 1726 poz. w wyk. 7) Runae Medelpadicae Olafa Celsiusa st. (Uppsala 1726, poz. w wyk.13), wydaną w tym samym roku polemikę Biörnera z Celsiusem pod tytułem Epistola responsoria ad... Olavum Celsium... de eiusdem dubiis circa delineationem et explicationem runarum (poz. w wyk. 6) oraz odpowiedź Celsiusa De monumentis quibusdam runicis epistola ad amicum (Uppsala 1727, poz. w wyk. 14). E. J. Biörner był zwolennikiem teorii historiozoficznej Olofa Rudbecka st. (1630-1702). Natomiast Olaf Celsius, botanik i lingwista, profesor uniwersytetu w Uppsali i opiekun młodego Linneusza, reprezentował odmienny pogląd na przeszłość Szwecji niż jego polemista. Drugi, niewielkich rozmiarów tomik, oprawiony w cielęcą skórę marmoryzowana, zawiera pamiętniki generała w armii francuskiej Claude'a Louis'a de Saint-Germain (Amsterdam 1780, poz. w wyk. 46). Oba egzemplarze zasiliły następnie księgozbiór biblioteki Sztabu Generalnego, natomiast do Warszawy dotarły w $1863 \mathrm{r}$.

Wspomniany wyżej siostrzeniec Matthiasa von Benzelstierna, Lars (Wawrzyniec) von Engeström był blisko związany z Polskąa ${ }^{29}$. Pełniąc funkcję szwedzkiego kanclerza i posła Gustawa III, przebywał w Polsce od 1787 r., początkowo w tajnej służbie, od 1790 r. oficjalnie jako akredytowany poseł. Związany z elitą obozu patriotycznego, uczestniczył aktywnie w pracach nad Konstytucją 3 Maja. W 1790 r. poślubił Rozalię Chłapowska, rok później, za wstawiennictwem Juliana Ursyna Niemcewicza otrzymał indygenat od króla Stanisława Augusta Poniatowskiego. Pod koniec życia

${ }^{29}$ W. Konopczyński, Engeström Wawrzyniec (Lars), PSB, t. 4, s. 272. 
osiadł w majątku Jankowice koło Poznania i tam zmarł. Lars Engeström podarował Aleksandrowi Batowskiemu (1760-1841) polskiemu arystokracie, szambelanowi królewskiemu i posłowi inflanckiemu na Sejm Czteroletni, rozprawę Du péril de la balance politique de l'Europe (Stockholm 1790, poz. w wyk.33), którą opatrzył notą donacyjną o treści: Donné par le Baron Engelstrom Ministre de Suede en Pologne, A Monsieur le Comte Batowski Député a la Diete constitutionnelle de Pologne: Varsovie 7. Mai 1791. Dzieło to, przypisywane różnym autorom, poświęcone jest sytuacji politycznej współczesnej Europy. Warszawski egzemplarz ma piękną oprawę, w skórę typu maroquin, w kolorze ciemnoczerwonym, ozdobioną klasycyzującymi tłoczeniami złoconymi z motywem meandra. W narożach zwierciadła odbito godło Szwecji - trzy korony. Całość dodatkowo zdobia złocone obcięcia kart. Oprawę wykonano zapewne w warsztacie szwedzkiego introligatora Johana Gottlieba Ditzingera ${ }^{30}$. Polskie thumaczenie tego traktatu, podjęte z inicjatywy Engeströma, ukazało się już w 1790 r. w Warszawie $^{31}$. Aleksander Batowski był bibliofilem, właścicielem biblioteki gromadzonej z zamiłowaniem i dużym nakładem środków finansowych ${ }^{32}$. Swą kolekcję sprzedał w 1826 r. Bibliotece Rady Stanu Królestwa Polskiego, skąd przeszła w 1868 r. do zbiorów Biblioteki Głównej, funkcjonującej od 1871 r. jako Biblioteka Cesarskiego [i.e. rosyjskiego] Uniwersytetu Warszawskiego.

Dość skromnie w omawianym zespole reprezentowane jest środowisko duchownych luterańskich. Chronologicznie pierwszy w tej grupie, Nicolaus Johannis Rudbeckius (1622-1676) urodzony w Västerås, rozpoczął studia w Uppsali w 1640 r., które od 1643 r. miał zamiar kontynuować w Niemczech. Jednak tego samego roku powrócił do rodzinnego miasta, aby objać stanowisko profesora retoryki w gimnazjum założonym przez swego ojca. W 1667 roku uzyskał tytuł doktora teologii na uniwersytecie w Uppsali, następnie otrzymał funkcję kaznodziei w Sztokholmie i nominację na biskupa diecezji Västerås. Wydanie dzieł greckiego poety Hezjoda (Amsterdam 1632, poz. w wyk. 23) kupił w Lubece, zapewne w 1643 r. Następny właściciel książki, prawdopodobnie w tym samym

${ }^{30}$ A. Herberg, Stockholms bokbindare 1460-1880, Stockholm 1960, Bd. 2, il. 33.

${ }^{31}$ [Peyssonel Claude Charles de, aut. domn.], O niebespieczeństwie wagi polityczney albo wykład przyczyn, które zespuły równnowazność na północy od wstapienia na tron rossyjski Katarzyny II [tłum. domn. Antoni Bieńkowski] - Brzeg [właśc. Supraśl, druk. OO. Bazylianów] 1790, zob. M. Cubrzyńska-Leonarczyk, Katalog druków supraskich, Warszawa 1996, poz. 367, 375; K. Estreicher, Bibliografia polska, Kraków, cz. 2, t. 6 , s. $474-475$.

${ }^{32}$ M. Brzdękiewicz, Księgozbiór Aleksandra Benedykta Batowskiego, [w:]w: Z Badań nad Polskimi Księgozbiorami Historycznymi, t. 1, red. B. Bieńkowska, Warszawa 1975, s. 127-146. 
roku otrzymał ją od młodego Rudbeckiusa, o czym poinformował w notatce: Non tam donum Elae Petri, quam a Nicolao Rudbeckio datum, it v. respice 27 Decemb[ris], A. 1643. Ostatecznie tomik Hezjoda znalazł się w rękach Polaka, burmistrza Warszawy Karola Zabrzeskiego (zm. ca 1680). Jego cenny, duży księgozbiór, złożony głównie z dzieł autorów klasycznych, spadkobiercy podarowali klasztorowi kamedułów bosych w Warszawie skąd trafił do BUW.

Johan Browallius (1707-1755) był profesorem nauk przyrodniczych w Turku, współpracownikiem i pierwszym autorem biografii Karola Linneusza. W 1749 r. otrzymał nominację na biskupa Turku (Åbo). Z czasem został wicekanclerzem Królewskiej Akademii Nauk w Turku oraz członkiem Królewskiej Szwedzkiej Akademii Nauk w Sztokholmie. Z jego kolekcji mamy cztery dzieła oznaczane zwięzłą notą własnościową Ex libris Joh[annis] Browallii. Sztokholmskie wydanie dziejów króla Ostrogotów Teodoryka pióra Johana Cochlaeusa (1699, poz. w wyk.16) wcześniej należało do Eliasa Brennera (1647-1717), zapewne fińskiego malarza na dworze króla Gustawa XI, rytownika, numizmatyka i cenionego autora katalogu monet i medali szwedzkich wydanego w 1691 r. Dwie inne rozprawy: Anselma de Boodt, Gemmarum et lapidum historia (Lugduni 1636, poz. w wyk. 9) oraz Hassiae subterranaeae specimen w opracowaniu niemieckiego teologa i matematyka Johanna Georga Liebknechta (Giessae 1730, poz. w wyk. 31) potwierdzają zainteresowanie Browalliusa naukami przyrodniczymi. Ponadto, z jego zbiorów jeszcze posiadamy panegiryk na cześć królowej Krystyny (Paryż 1655, poz. w wyk. 21).

Duży księgozbiór zgromadził biskup Turku i arcybiskup Uppsali od 1775 r. Carl Fredrik Mennander (1712-1786). Mennander wykładał fizykę i teologię w Turku, interesował się również naukami przyrodniczym. Książki oznaczał ciekawym ekslibrisem graficznym z motywami Jezusa Ukrzyżowanego na Golgocie oraz otwartej księgi położonej na pastorale. Ponad krzyżem umieszczono motto „CruciFixus Amor Meus”, z ukrytymi inicjałami właściciela: $\mathrm{C}$ [arl] $\mathrm{F}$ [redrik] $\mathrm{A}$ [rchiepiscopus] $\mathrm{M}$ [ennander]. Kilkaset książek podarował bibliotece akademii w Turku, która spłonęła w pożarze w 1827 r. Obecnie kilka egzemplarzy z jego ekslibrisem przechowuje biblioteka narodowa w Helsinkach ${ }^{33}$. W warszawskiej książnicy uniwersyteckiej odnotowano dotychczas cztery dzieła z jego kolekcji. Dwa z nich odnoszą się do Szwecji, a mianowicie rozprawa Linneusza o rodzimej faunie (Sztokholm 1746, poz. w wyk. 32) oraz biografia króla Gustawa II Adolfa, autorstwa Eleazara de Mauvillon (Amsterdam 1764,

\footnotetext{
${ }^{33}$ Kwerendę przeprowadzono we wrześniu 2007.
} 
poz. w wyk. 34). Ponadto, w Warszawie mamy historię podboju Meksyku opisana przez Antonia de Sollis (La Haye 1692, poz. w wyk. 50) oraz jeden z tomów antologii Elegantiores praestantium virorum satyrae, wydanej w Lejdzie przez Jana le Maire (poz. w wyk. 18). Książki arcybiskupa Mennandra posiadają skromne oprawy, w cielęcą skórę lub półskórek nałożone na tekturę.

Zbiory Michaela Hermoniusa (1680-1749), absolwenta uniwersytetu w Uppsali w 1706 r., pastora w kościele pw. św. Marii Magdaleny w Sztokholmie, reprezentowane są przez jedną książkę. Jego podpis, uzupełniony o datę $d$ [ie] 20 octob[ris] 1706, widnieje na recto dolnej oprawy woluminu, zawierającego jedną z bardziej znaczących prac w dorobku niemiecko-szwedzkiego humanisty i profesora w Uppsali Johana Scheffera Memorabilium Sueticae gentis (Hamburg, Sztokholm 1687, poz. w wyk.48).

Ciekawie prezentuje się grupa uczonych, profesorów i absolwentów uniwersytetu w Uppsali. Prezentację zacznijmy od interesującego dla kultury szwedzkiej egzemplarza traktatu Friedricha Lindenbroga $\mathrm{Di}$ versarum gentium historiae antique scriptores tres (Hamburg 1611, poz. w wyk. 30), opatrzonego licznymi łacińskimi adnotacjami. Autorem marginaliów był profesor medycyny i botanik Olof Rudbeck st., wieloletni zasłużony rektor uniwersytetu. Zasłynął on jako autor fantastycznego dzieła historycznego Atlantica, w którym dowodził, że starożytna Szwecja była kolebką cywilizacji europejskiej, a język łaciński i hebrajski mają swoje korzenie w języku szwedzkim. Teoria ta znacząco wpłynęła na ukształtowanie się szwedzkiej tożsamości narodowej, ale miała też licznych przeciwników. Następnym właścicielem dzieła stał się jego syn Olof (1660-1740), ornitolog i botanik, a od 1692 r. następca ojca na stanowisku profesora medycyny. Po śmierci Rudbecka mł. książka nadal pozostawała w mieście uniwersyteckim, bowiem jej kolejny właściciel, Jacob Larsson Arrhenius (1721-1791), syn profesora historii Larsa (1680-1730), piastował urząd sekretarza kanclerza uczelni w latach 1750-1752. Marginalia Olofa Rudbecka st. zidentyfikował Johan Lundblad (1753-1820), poeta i filolog, profesor uniwersytetu w Lund, o czym dowiadujemy się z notatki: Notulas marginales sua ipsius manu Ol. Rudbeckius senior adjecit, uti ex annotatione cujusdam in pag. 79 videre licet: sed nonnullae etiam recentiori stilo exaratae Joh. Lundblad, Prof. quondam Lundensi debentur. Książka ma oryginalną oprawę w tekturę obciagnięta pergaminem z zachowanymi resztkami wiązań. Oba lica okładzin otrzymały jednolitą dekorację tłoczoną złotem, obecnie już nieco wytartym. W zwierciadle umieszczono 
plakietę z motywem maureski, natomiast w narożach podwójnej ramki strychulcowej tłoki z niewielkim kwiatonem.

Dwujęzyczne, łacińsko-szwedzkie dzieło Carla Alexandra Clerck'a Svenska spindlar (Sztokholm 1757, poz. w wyk. 15) reprezentowane jest egzemplarzem, na którym podpisał się Carl Magnus Blom (1737-1815). Urodzony w Smalandii, ukończył studia teologiczne i medyczne w Uppsali pod kierunkiem Linneusza. Gromadził książki oprawione jednolicie w szary papier, głownie z zakresu medycyny, które podarował Collegium Medicum oraz Towarzystwu Medycznemu. Obecnie znajdują się one w Hagströmer Biblioteket w Sztokholmie ${ }^{34}$.

Właścicielem kolejnego traktatu, autorstwa Petera von Musschenbroek Physicae experimentales (Lejda 1729, poz. w wyk. 37) był Johan Carl Wilcke (1732-1796), student w Uppsali w 1749 r., następnie profesor fizyki i członek akademii nauk. Później egzemplarz ten należał do Petera Petersena (1767-1850), mineraloga pochodzącego z Trondheim, absolwenta akademii górniczej w Kongsberg w 1793 r.

Pierwsze wydanie kroniki Gotlandii, napisanej przez biskupa Visby - Hansa N. Strelowa (Kopenhaga 1633, poz. w wyk. 51), miał w swoich zbiorach Eric Michael Fant (1754-1817). Książkę tę nabył zapewne w czasie studiów w Uppsali, bowiem nota własnościowa uzupełniona jest informacją Upsala 1774. Fant po ukończeniu studiów w 1776 r. pracował jako asystent $\mathrm{w}$ bibliotece uczelnianej, kilka lat później obronił doktorat z teologii, a w 1789 r. przyjął święcenia kapłańskie. Był członkiem Towarzystwa Literackiego i profesorem historii w Uppsali. Jednakże pierwszy ujawniony właściciel tej kroniki to Johann Birth (zm. 1649), student teologii i filozofii w Królewcu, który na jednej z kart ochronnych zamieścił krótką biografię autora tego dzieła.

Szwedzkie wydanie pracy J. Richardsona Hallandia antiqua et hodierna (Sztokholm 1752-73, poz. w wyk. 45) opatrzył autografem Johan Erik Noréen, sekretarz kanclerza uniwersytetu w Uppsali w 1773 r. Inną zaś rozprawę dotyczącą monet francuskich (Amsterdam 1692, poz. w wyk. 29) otrzymał od niego w 1805 r. Erik Götlin (1744-1830), profesor retoryki, znawca monet islamskich oraz bibliotekarz i kurator kolekcji numizmatycznej przez blisko 40 lat. Götlin opublikował w1806 r. monografię De initiis monetae Svecanae, cenioną wśród znawców monet szwedzkich.

Do tego samego środowiska należał Olof Matthias Ullgren, respondent w Uppsali w roku 1806, właściciel rozprawy o tematyce numizmatycz-

${ }^{34}$ Zob. http://www.hagstromerlibrary.ki.se/author.php?id=4 [I 2013]. 
nej Kurzgefasste Anfangsgründe zur alten Numismatik autorstwa Josepha H. von Eckhela (Wiedeń ok. 1787, nr w wyk. 17).

Natomiast Eric Bergstrom, adiunkt na wydziale teologicznym w Uppsali miał w swoich zbiorach historię Rosji w języku szwedzkim, autorstwa Petrusa Petrejusa (Sztokholm 1614-15, poz. w wyk. 39).

Wielki islandzki poeta Snorri Sturlasson (ok. 1171-1241) zajmuje szczególne miejsce w historii krajów nordyckich. Był nie tylko poeta, ale też autorem sag, historykiem i zasłużonym politykiem. Dzieje krajów nordyckich jego pióra w wydaniu sztokholmskim z 1697 r. (poz. w wyk. 49) należały do Sebastiana Grave (1684-1747), prawdopodobnie inżyniera górnictwa i założyciela huty żelaza w Gravendal ok. 1720 r. Na tym egzemplarzu widnieje ponadto autograf bliżej niezidentyfikowanego właściciela, podpisanego J. N. Lindahl.

Inna rozprawa wspominanego już wyżej historyka J. E. Biörnera Inledning yfwerborna göters gamla häfder Afwerborna Göters gamla Hafder (Sztokholm 1738, poz. w wyk. 5), opatrzona jest interesującym zapisem donacyjnym: 1802 Tillfallit Krigs Commissarien Johan Gabrielsson Sundvicks Fru-Hedvig Susanna Mollin i arf efter Dess ModerBroder Rectoren i Abo Magister Herr Gustaf Chronander. 1803 den 20. Augusti gifven till Läse Bibliotheket $i$ Wasa. J G Sundvik, z którego wynika, że książkę tę otrzymała Hedwig Susanna Mollin, późniejsza żona komisarza wojennego Johana Gabrielssona Sundvika, w spadku po bracie swojej matki, niejakim Gustafie Chronanderze (1753-1801). Rozpoznajemy w nim rektora uniwersytetu $\mathrm{w}$ Turku, który opatrzył to dzieło dopiskiem rare et recherche ${ }^{35}$. W 1803 r. wolumin ten przekazano do biblioteki publicznej w Wasa. To dwujęzyczne, łacińsko-szwedzkie dzieło, dedykowane przez autora m.in. dwojgu sławnym uczonym: Karolowi Linneuszowi i Andreae Celsi, trafiło do Warszawy z fragmentem zbiorów wspomnianego wyżej J. P. Suchtelena.

Johann David Flintenberg (1762-1819), historyk i dyrektor muzeum królewskiego w Sztokholmie, oznaczał swoje książki ekslibrisem z popularnym w XVIII w. wizerunkiem wnętrza bibliotecznego. Na wykonanym techniką miedziorytową ekslibrisie, pomiędzy regałami bibliotecznymi umieszczono napis „Lån-Bibliothek”, a nad wejściem (w owalnym zwierciadle) monogram „IDF”. Tym znakiem własnościowym oznaczone zostały pamiętniki Johana Ludwiga Hordta, wydane w Berlinie w 1788 r., wyposażone w ładną sztychowaną kartę tytułową (poz. w wyk. 24). Odmienny, typograficzny ekslibris z napisem: „Kongl. Secreteraren J.D. Flin-

\footnotetext{
${ }^{35}$ Podziękowania za thumaczenie kieruję do dr. Otfrieda Czaiki z Biblioteki Narodowej w Sztokholmie.
} 
tenbergs Lån-Bibliothek" znajduje się na okładzinie górnej verso zabezpieczajacej tom Ephemerides sive iter Danicum, Svecicum, Polonicum Charles'a Ogiera (1595-1654, poz. w wyk. 38), francuskiego dyplomaty i uczestnika rozejmu polsko-szwedzkiego w Sztumskiej Wsi w 1635 r. Jego Dziennik z podróży do Polski w latach 1635-1636 był parokrotnie wznawiany i nadal cieszy się zainteresowaniem polskich historyków.

$\mathrm{Na}$ koniec pozostaje przedstawienie kilku dzieł oznaczonych notami proweniencyjnymi przez osoby, o których informacje są nader skromne lub niepewne.

Andreas Fellenius (1683-1719) - zapewne respondent w Uppsali w 1716 r. $^{36}$, miał w swoich zbiorach monografię Kempenskiölda $H i$ storiae... Gustavi I Svecorum... regis... libri V (Strengnesiae 1629, poz. w wyk. 27). Książka nosi ślady intensywnego użytkowania przez kilku innych właścicieli, być może studentów tegoż uniwersytetu.

Do Henrica Aulina (1737-1819), respondenta w Turku (Åbo) w 1759 r. ${ }^{37}$ należał tomik omawiający dzieje wojenne króla Karola XII, autorstwa Simona Isogaeusa (Stockholm 1714, poz. w wyk. 25).

Właścicielem woluminu zakupionego na aukcji książek należących do Heinricha Jacoba Siversa (1708-1758) w 1756 r. został Johann Gustav Psilanderhielm (1723-1782), kompozytor i kopista pochodzacy z rodziny arystokratycznej (poz. w wyk. 1).

Niejaki Jakob Ståhle opatrzył swoim autografem niewielkich rozmiarów rozprawę teologiczną Förklaring öfwer catechismum napisaną przez

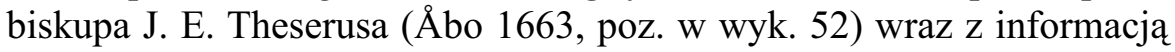
o nabyciu jej na aukcji w Turku w $1797 \mathrm{r}$. Ta sama pozycja, pozbawiona karty tytułowej zapewne jeszcze w XIX w., oznaczona jest pieczęcią heraldyczna parokrotnie wspominanego J. P. Suchtelena.

Zagadkowy dopisek widzimy na ekslibrisie graficznym szwedzkiej rodziny Silfverstolpe, na którym atramentem przy nazwisku napisano inicjały „F. D”. Kto się pod nimi kryje, nie wiemy (poz. w wyk. 12).

Znana rozprawa J. G. Meusela Anleitung zur Kenntniss der Europäischen Staatenhistorie (Leipzig 1775, poz. w wyk. 36) opatrzona jest notą proweniencyjną: 28 G[ustav ?] Theorin Stockholm 1819. Autorem zapiski mógł być Gustav Theorin, respondent w Greisfwaldzie w 1806 r. ${ }^{38}$

${ }^{36}$ Dissertatio geographica de fertilitate regionum Europaearum... pro gradu publico examini modeste submittit alumnus regius Andreas Fellenius... Uppsaliae [1716].

${ }^{37}$ Deo duce... disquisitionem modestam de usu et ab usu methodi mathematicae in theologia revelata... subjiciunt Christianus Cavander... et Henricus Aulin... Aboae [1759]. 1806 .

${ }_{38}$ Comparatio inter privatam puerorum educationem et publicam..., Gryphiswaldie 
Warto też wskazać ładnie oprawione wydanie psałterza w języku szwedzkim (Sztokholm 1619, poz. w wyk. 42), oznaczone tłoczeniami „I. A. R.” na okładzinie górnej. Prawdopodobnie ten sam właściciel podpisał się dwukrotnie na stronie tytułowej: Johan A[...?] Reijmer mpp. Pomimo tego, że osoba posesora jest trudna do zidentyfikowania, zapewne była związana ze Szwecja. Ponadto, na grzbiecie oprawy znajduje się biblioteczna nalepka sygnaturowa, identyczna z zachowanym fragmentem, który widnieje na oprawie Biblii z kolekcji Johana Oxenstierny, opisanej powyżej. Pochodzenie obu nalepek pozostaje również niezidentyfikowane.

Na wzmiankę zasługuje także klocek introligatorski, zawierający osiemnastowieczną reedycję psalmów z 1695 r. (Sztokholm 1797, poz. wyk. 41) oraz Evangelier och Epistlar, wytłoczonych w oficynie Johana P. Lindta w Orebro (poz. w wyk. 19) tego samego roku. Na recto frontispisu znajduje się informacja zapisana w języku szwedzkim o dacie śmierci Susanny De Mare, urodzonej Brantberg 18 grudnia 1837 r. Książka zatem mogła należeć do któregoś z członków tej rodziny. Oprawa tego tomiku w skórę cielęcą obciagniętą na desce, nosi ślady ciekawych tłoczeń wykonanych radełkiem na ślepo. Do stołecznej książnicy uniwersyteckiej wolumin ten został włączony razem z księgozbiorem Zboru Ewangelicko-Reformowanego w Warszawie, przekazanego po drugiej wojnie światowej.

Wymienione wyżej osoby nie zamykają listy byłych szwedzkich właścicieli ksiag zgromadzonych w zbiorach Biblioteki Uniwersyteckiej w Warszawie. W toku dalszych badań proweniencyjnych mogą wyłonić się następne, nieznane egzemplarze i nazwiska posesorów. Omówiony zespół kilkudziesięciu druków dotarł do uniwersyteckiej książnicy w sposób dość przypadkowy, jednak można było wyodrębnić w nim określone grupy właścicieli i zasygnalizować pewne zależności istniejące pomiędzy tymi osobami. Splot różnych okoliczności politycznych spowodował, że książki z proweniencjami polskimi znajdują się dzisiaj w wielu zagranicznych bibliotekach, a w rodzimych księgozbiorach mamy z kolei liczne egzemplarze $z$ tzw. proweniencjami obcymi. Zwłaszcza te ostatnie, ze względu na ich różnorodne pochodzenie, stanowią ciekawe i inspirujące źródło do interdyscyplinarnych badań nad dziejami kultury europejskiej. Rosnące wśród badaczy książki historycznej zainteresowanie rekonstrukcją dawnych bibliotek prywatnych i publicznych, nawet przy wykorzystaniu nowoczesnych technik, długo jeszcze nie zostanie zrealizowane. Jedna z przyczyn tego stanu rzeczy są niełatwe do odtworzenia losy książek, które na przestrzeni wieków zmieniały swoich właścicieli, a często też wygląd zewnętrzny, co doprowadziło do bezpowrotnej utraty pierwotnych cech indywidualnych wielu egzemplarzy. 
Wykaz dzieł:

1. Arnkiel, Troels: Aussführliche Eröffnung... - Hamburg, T. von Wiering, $1703 ; 4^{\circ}$.

Prow.:

1. E Biblioth[eca] Henr[rici] Jac[obi] Sivers 1756.

2. Post D[ominum] Sievers auctione publica aquis[itum] a Joh[anne] Gust[avo] Psilanderhielm - XVIII w.

3. Biblioteka General'nago Štaba - ekslibris, nalepka sygn. (5642) na grzb., XIX w

Opr.: tekt., pergamin - XVIII w.

8.11.14.19/2

2. Bacallar y Sanna, Vincente: Commentarios de la guerra de Espana e historia de su rey Phelipe V... - Genova, M. Garvizza, [ca 1725], 2 wol.; $4^{\circ}$. Prow.:

1. E[ric] Bergstedt 1779.

2. Biblioteka General'nago Štaba - ekslibris, nalepka sygn. (7290) na grzb., XIX w.

Opr.: pergamin - XVIII w.

9.3.14.20/1

3. Bartholin, Thomas: Historiarum anatomicarum rariorum, centuria III et IV... - Hafniae $1657 ; 8^{\circ}$.

Prow.:

1. [Carl Gustaf] Tessin - XVIII w.

2. [Biblioteka Imperatorskoj Akademii Nauk - St. Petersburg] - sygn., XIX w.

3. Biblioteka Główna w Warszawie - pieczęć, XIX w.

Opr.: tekt., pergamin, obc. nakrapiane niebiesko - XVII w.

12.11.14.29b/1

4. [Bibeln]: Biblia thet ähr hela the Helga Schrifft på svenska med wtgånde verser... - Leiden, J. Marci, 1635; $8^{\circ}$.

Prow.:

Johannes Oxenstierna Axelij Filius Comes de Sovermore, Liber Baro de Kimitso[Kimito] etc Natus Sum Stockholm 24 Junij sive die S. Johannis Baptistae Anno post Verbum in Carnem ventum 1611 ...12.. 13 (etc. lata wymienione do) 57 hunc Johanis 57 impleo annum aetatis 46tum. Data lektury: den 26 April Ann: 1639, niżej inną ręką: ...in d[ie] 28 Novemb[ris] 1655. Podkreślenia, marginalia ręką Joh. Oxenstierny - XVII w. Liczne zapiski religijne ołówkiem, po szwedzku i łacinie, inną ręką rysunki - obecnie wyblakłe. Na grzb. fragm. nalepki sygn. 
Opr.: tekt., skóra wiśniowa typu maroquin, zdobiona w stylu á la éventail (motyw wachlarza w zwierciadle, narożach i na grzb.), obc. złocone, puncowane we wzory kwiatowe - XVII w.

28.20.3.4047 cim.

5. Biörner, Eric Julius: Inledning yfwerborna göters gamla häfder Afwerborna Göters gamla Hafder... - Stockholmiae, J. L. Horrn, 1738; $2^{\circ}$. Prow.:

1. Gustavus Jacobi Chronander - XVIII w.

2. 1802 Tillfallit Krigs Commissarien Johan Gabrielsson Sundvicks FruHedvig Susanna Mollin i arf efter Dess ModerBroder Rectoren i Abo Magister Herr Gustaf Chronander. 1803 den 20. Augusti gifven till Läse Bi bliotheket i Wasa. J G Sundvik.

3. [Johann Peter] Suchtelen - pieczęć, XVIII/XIX w.

4. Biblioteka General'nago Štaba - ekslibris, nalepka sygn. (5781) na grzb., XIX w.

Opr.: tekt., pergamin - XVIII w.

8.4.1.4/3

6. Biörner, Eric Julius: Epistola responsoria ad... Olavum Celsium... de eiusdem dubiis circa delineationem et explicationem runarum. - [Stockholm: s.n.] $1726 ; 4^{\circ}$.

Prow.:

1. M[atthias] Benzelstierna - ekslibris, XVIII w.

2. Biblioteka General'nago Štaba - ekslibris (naklejony na poprzednim), nalepka sygn. (6789) na grzb., XIX w.

Opr.: tekt., półskórek, papier marmurkowy - XVIII w.

9.3.14.9 adl./1

7. Biörner, Eric Julius: Prodromus tractatuum de geographia Scandinaviae veteri et historiis Gothicis... - Stockholmiae, J. L. Horrn, [1726]; $4^{\circ}$.

Prow. i opr. zob. poz. 6.

9.3.14.10 adl./1

8. Boecler, Johann Heinrich: Historia belli Danici... - Stockholmiae, N. Wankijff, $1676 ; 4^{\circ}$.

Prow.:

1. O[lof] Hermelin - XVII w.

2. Biblioteka General'nago Štaba - ekslibris, nalepka sygn.(4943) na grzb., XIX w.

Opr.: tekt., pergamin - XVII w.

9.6.5.1/1 
9. Boodt, Anselmus de: Gemmarum et lapidum historia... - Lugduni Batavorum, J. Maire, 1636; $8^{\circ}$.

Prow.:

1. Henricus Schmiedt Phil[osophiae] et Med[icinae] D[octor] - XVII w.

2. Ex libr[is] Joh[annis] Browallii, (tą samą ręką ?) 1737 Jan[uarii] ... (nieczyt.)

3. Mineralogia - pieczęć [= Akademia Medyko-Chirurgiczna w Warszawie], XIX w.

Opr.: tekt., pergamin - XVII w.

3.9.10.21/1

10. Boulainvilliers, Henri: Etat de la France dans lequel on voit tout ce qui regarde le gouvernement... - Londres, T. Wood, S. Palmers, 1737; $8^{\circ}$.

Prow. :

1. Jean Georg Lillienberg - XVIII w.

2. Biblioteka General'nago Štaba - ekslibris, nalepka sygn. (1427) na grzb., XIX w.

Opr.: tekt., skóra cielęca, łłocz. złocone, wyklejki z papieru marmurkowego, obc. marmurkowe - XVIII w.

\subsubsection{7/1}

11. Camden, William: Rerum Anglicarum et Hibernicarum annales regnante Elisabetha... - Lugd. Batavorum, typis Elseviriorum, 1639; $8^{\circ}$. Prow.:

1. S[chering ?] R[osenhane?] - XVII w.

2. Ex bibliotheca Johannis Rosenhane A. 1673.

3. Ex Bibliotheca C[arl] F[riedrich] ab Eckleff - ekslibris, XVIII w.

4. Biblioteka General'nago Štaba - ekslibris, nalepka sygn. (2264) na grzb., XIX w.

Opr.: tekt., pergamin - XVII w.

9.2.16.10/1

12. Cavard, André: Les memoires du comte de Vordac... - Paris, G. Saugrain, 1730, 2 wol.; $8^{\circ}$.

Prow.:

1. F D (dopisane rps.) Silfverstolpe - ekslibris, XVIII w.

2. Biblioteka General'nago Štaba - ekslibris, nalepka sygn. (3884) na grzb., XIX w.

Opr.: tekt., półskórek, papier marmurkowy, tłocz. złocone na grzb. - XVIII w. 9.6.8.19/1

13. Celsius, Olaf st.: Runae Medelpadicae... - Upsaliae, typis Wernerianis, $1726 ; 4^{\circ}$. Prow. i opr. zob. poz. 6.

9.3.14.10a adl./1 
14. Celsius, Olaf st.: De monumentis quibusdam runicis epistola ad amicum. Upsaliae: literis Wernerianis, $17274^{\circ}$.

Prow. i opr. zob. poz. 6.

9.3.14.11 adl./1

15. Clerck, Carl Alexander: Svenska spindlar... Aranei Svecici descriptionibus et figuris aeneis illustrati... - Stockholmiae, L. Salvii, 1757; $4^{\circ}$.

Prow.:

Carl M[agnus] Blom - XVIII w.

Opr.: tekt., skóra cielęca marmoryzowana, tłocz. złocone na grzb., obc. złocone, wyklejki z papieru marmurkowego - XVIII w.

3.16.4.2/2

16. Cochlaeus, Johannes: Vita Theodorici regis Ostrogothorum... - Stockholmiae, Literis Enaeanis, 1699; $4^{\circ}$.

Prow.:

1. Ex Bibliotheca El[iae] Brenn[i ?] II:9:8:1: d[ie] 30 Sept[embris] 1717.

2. Ex libris Joh[annis] Browallii - XVIII w.

3. Biblioteka General'nago Štaba - ekslibris, nalepka sygn. (5670) na grzb., XIX w.

Opr.: tekt., pergamin - XVIII w.

8.9.8.30/1

17. Eckhel, Joseph H. von: Kurzgefasste Anfangsgründe zur alten Numismatik... - Wien, J. von Kurzbek, [ca. 1786]; $8^{\circ}$.

Prow.:

1. O[lavus ?] M[atthias ?] Ullgren 1806, obok tą samą ręką sygn.: No 292. - skreślone.

2. O.L. Berndes 1820.

Opr.: karton niebieski - XIX w.

8.7.8.9/2

18. Elegantiores praestantium virorum satyrae, distributur in tomos duos. - Lugduni Batavorum, ex off. Io. Maire, $1655 ; 12^{\circ}$.

Prow.:

1. C[arl] F[redrik] Mennander - w t. 1, XVII w.

2. Ex bibliotheca Johannis Rosenhane 1673 - w t. 2.

Opr.: tekt., pergamin - XVII w.

17.2.12.24/1

19. [Evangelier och Epistlar]: De årlige Evangelier ch Epistlar... jåmte bone-boken... - Orebro, J.P. Lindth, 1797; $12^{\circ}$.

Prow. i opr. zob. poz. 41.

28.20.4.4430 adl. 
20. Figueroa, Garcias de Silva: L'Ambassade de D. Garcias de Silva Figueroa en Perse contenant la politique de ce Grand Empire les moeurs du roy Schach Abbas... - Paris, I. du Puis, 1657; $4^{\circ}$.

Prow.:

1. Constantie (Constantir?) don. Ju... [?] 1667.

2. Clas Ekeblad, obok mała pieczęć lakowa - XVII/XVIII w.

3. Biblioteka General'nago Staba - ekslibris, nalepka sygn. (5861) na grzb., XIX w.

Opr.: tekt., pergamin - XVII w.

8.7.10.29/2

21. Freinshem, Johann: Harangue panegyrique a la vertu et l'honneur de la... madame Christine reyne de Svede... - Paris, P. Des-Haybes, A. Cellier, $1655 ; 24^{\circ}$.

Prow.:

1. Ex lib[ris] Joh[annis] Browallii - XVIII w.

2. Biblioteka General'nago Štaba - ekslibris, nalepka sygn. (5319) grzb., XIX w.

Opr.: tekt., skóra cielęca marmoryzowana, tłocz. złocone - XVII w.; brak okł. dolnej, fragm. klocka.

8.9.2.34/1

22. Gonzalez de Mendoza, Juan: Nova et succincta... historia de... Regno China... - Francofurdi a.M., [s.n., 1589]; $8^{\circ}$.

Prow.:

1. J. Kinschot [?] $\mathrm{mp}-\mathrm{XVII} \mathrm{w}$.

2. Ex Bibliotheca Johanis Rosenhane 1673.

3. Bibliotheca Suchtelen. - ekslibris oraz pieczęć, XVIII/XIX w.

Opr.: tekt., skóra kozia, tłocz. złocone na grzb. - XVIII/XIX w.

Sd.608.4278

23. Hesiodus: Collegium Hesiodeum ubi Graeca Hesiodi Ascraei Carmina... Amstelrodami, H. Laurentius, 1632; $8^{\circ}$.

Prow.:

1. Nicolaus Rudb[eckius] me emit Lubecae t. ${ }^{1 / 2}$ [...] - XVII w.

2. Non tam donum Elae Petri, quam a Nicolao Rudbeckio datum, id v. respice 27 Decemb[ris] A[nno] 1643.

3. Christopho[ri] Sebastianij Scesae Bra[u]nsvig[ie]ns[is] Anno 1646.

4. Sum Caroli Zabrzeski (dopisane przed zapisem) Ex Donatione G[enerosi] (po zapisie) P[incernae] Treb[owlensis] oretur pro eo.

5. [Karmelici bosi - Warszawa] - wytarte, XVIII w.

6. Bank Polski - Warszawa, sygn., XIX w.

Opr.: deska, pergamin - XVII w.

28.20.3.2445 
24. Hordt, Johan Ludwig: Mémoires d'un gentilhome Suédois... - Berlin, S. Pitra, $1788 ; 8^{\circ}$.

Prow.:

1. Lan = Bibliothek (niżej monogram:) I[ohann] D[avid] F[lintenberg] ekslibris, wyżej sygn. atr. XIY: 18/c:4., XVIII/XIX w.

2. Biblioteka General'nago Štaba - ekslibris, nalepka sygn.(7035) na grzb., XIX w.

Opr.: tekt., półskórek, papier marmurkowy, tłocz. złocone na grzb. - XVIII w.

8.16.3.11/1

25. Isogaeus, Simon: Carla-seger-skiöld hwilken den stormätigste konung Carl XII... - Stockholm, M. Laurelio, 1714; $8^{\circ}$.

Prow.:

1. Henrici Aulin (zamazane) - XVIII w.

2. Biblioteka General'nago Štaba - ekslibris, nalepka sygn. (3018) na grzb., XIX w.

Opr.: tekt., skóra cielęca marmoryzowana, tłocz. złocone na grzb. - XVIII w.

8.13.9.19/1

26. Jan Damasceński św. [aut. domn.]: Historia de vitis et rebus gestis ss. Barlaam Eremitae et Iosaphat Indiae regis... - Coloniae Agrip., Jod. Kalcoven, $1643 ; 12^{\circ}$.

Prow.:

1. zapis zamazany.

2. Denna book Kiöpte iag Guus [?] Brodiins pa ${ }^{\circ}$ en auction for 19 öre Koppmtt i Upsala, den 1 Maij $A^{\circ} 1704$.

3. Liber Josephi Plachecki - przekreśl., XVIII w.

Opr.: tekt., pergamin, obc. nakrapiane granatowo - XVII/XVIII w.; grzb. uszkodz.

$7.42 .7 .7 / 1$

27. Kempenskiöld, Samuel: Historiae... Gustavi I Svecorum... regis... libri V... Strengnesiae, typis Paulinianis, J. Barkenio, 1629; $8^{\circ}$.

Prow.:

1. Possessio Olaf Petrij Strengnensis (częśc. skreślone) - XVII w.

2. Possesio sum ego 1663 Jacobi Andreae A[ngermanis], powtórz. Jacobus Andreas Angermanis.

3. Johannes Laurentius Aug. Sidenius (nadpisane na poprzednim zapisie) XVII w.

4. Andreas Fellenius - XVII/XVIII w.

5. Biblioteka General'nago Štaba - ekslibris, nalepka sygn. (6536) na grzb., XIX w.

Sentencje łac., podkreślenia w tekście, bazgroły. 
Opr.: deska, skóra cielęca - XVII w.; zniszcz.

8.16.14.37/1

28. Kopernik, Mikołaj: De revolutionibus orbium coelestium libri VI... - Basileae, Officina Henricpetrina, 1566; $2^{\circ}$.

Prow.:

1. Mauritius Hassiae Landgravius 3 F[ebruarii] A. [15]94 dedit a Nicolao Chesnecophero Sueco oraz Nicolaus Chesnecopherus Suecus - na opr.

2. L[yceum] V[arsaviense] - XIX w.

Opr.: papier, pergamin $-\mathrm{XVI} w$.

Sd.612.463

29. Le Blanc, François: Traite historique des monnoyes de France... [acc.:] Dissertation historique sur quelques monnoyes De Charlemagne... - Amsterdam, P. Mortier, $1692 ; 4^{\circ}$.

Prow.:

1. Johan. Er. Noreen d[ono] d[edit] Erico Götlin 1805.

2. $O$ L Berndes 1820.

3. Biblioteka General'nago Štaba - ekslibris, nalepka sygn. (3308) na grzb., XIX w.

4. Biblioteka Główna w Warszawie - pieczęć, XIX w.

Opr.: tekt., pergamin - XVII w.

9.7.2.5/2

30. Lindenbrog, Friedrich: Diversarum gentium historiae antique scriptores tres... - Hamburgi, M. Hering, 1611; $4^{\circ}$.

Prow.:

1. zapis wydrapany.

2. [Olof Rudbeck st.] - marginalia, XVII w.

2. Ex Bibliotheca O[lofae] Rudbeckii filii. Const. [...]-XVII/XVIII w.

3. Jacob L[arsson] Arrhenius Ups[alae] d. 21 Mart. 1741.

4. Notulas marginales sua ipsius manu Ol[afus] Rudbeckius senior adjecit, uti ex annotatione cujusdam in pag. 79 videre licet: sed nonnullae etiam recentiori stilo exaratae Joh[annis] Lundblad, Prof. quondam Lundensi debentur. E. L[undblad?] - XVII/XVIII w.

5. Biblioteka General'nago Štaba - ekslibris, nalepka sygn. (5502) na grzb., XIX w.

Opr.: tekt., pergamin, tłocz. złocone, resztki wiązań - XVII/XVIII w.

8.15.3.17/2

31. Liebknecht, Johann Georg: Hassiae subterranaeae specimen... - Giessae, Francofurti, E.H. Lammers, 1730; $4^{\circ}$.

Prow.:

1. Ex lib[ris] Joh[annis] Browallii-XVIII w. 
2. [Akademia Medyko-Chirurgiczna w Warszawie] - sygn., XIX w. Opr.: tekt., półskórek, papier marmurkowy - XVIII w.

3.8.4.28/2

32. Linné, Carl von: Fauna Svecica... - Stockholmiae, L. Salvii, 1746; $8^{\circ}$. Prow.:

1. P J L (? watpliwe) - monogram wiązany, XVIII w.

2. Carl Fredrik Mennander - ekslibris, XVIII w. Opr.: tekt., półskórek, papier marmurkowy - XVIII w. 3.6.8.54/1

33. Mallet du Pan [= Peyssonel, Claude Charles de, aut. domn.]: Du peril de la balance politique de l'Europe. - Stockholm, A. Zetterberg, $1790 ; 8^{\circ}$. Prow.:

1. Donné par le Baron Engelstrom Ministre de Suede en Pologne, A Monsieur le Comte Batowski Député a la Diete constitutionnelle de Pologne : Varsovie 7. Mai 1791.

2. Aleksandre Batowski oraz ekslibris, XIX w.

Opr.: tekt., skóra czerwona typu maroquin, tłocz. złocone - XVIII w. 6.28.3.20/1

34. Mauvillon, Eléazar de: Histoire de Gustave-Adolphe roi de Suede... - Amsterdam, Z. Chatelain, $1764 ; 8^{\circ}$.

Prow.:

1. Carl Fredrik Mennander - ekslibris, XVIII w.

2. Biblioteka General'nago Štaba - ekslibris, nalepka sygn. (5701) na grzb., XIX w.

Opr.: tekt., skóra cielęca, tłocz. złocone na grzb. - XVIII w.

8.18.14.22/1

35. Mekerchus, Adolphus: De veteri et recta pronuntatione linguae Graecae Prow.: commentarius... - Antverpaie, ex off. Christ. Plantini, 1576; $8^{\circ}$.

1. zapis w poł. ucięty.

2. M[agnus] G[abriel] D[e] L[a] G[ardie] C[omes] I[n] L[eckö] E[t] A[rensburg], h. własny złożony - pieczęć lakowa, XVII w.

Marginalia nieliczne kilku rąk, podkreślenia - XVII w.

Opr.: tekt., pergamin - XVII w.

Sd.608.4909

36. Meusel, Johann Georg: Anleitung zur Kenntniss der Europäischen Staatenhistorie... - Leipzig, Fritsch, 1775; $8^{\circ}$.

Prow.:

1. 28 G[ustav ?] Theorin Stockholm 1819. 
2. Biblioteka General'nago Štaba - ekslibris, nalepka sygn. (5389) na grzb., XIX w.

Opr.: tekt., półskórek, papier marmurkowy, tłocz. złocone na grzb. - XVIII/XIX w. 8.16.4.22/1

37. Musschenbroek, Peter van: Physicae experimentales et geometricae... dissertationes... -Lugduni Batavorum, S. Luchtmans, 1729; $4^{\circ}$.

Prow::

1. Joh[an] Carl Wilcke ... bok af Lismedieg Heidenstam for 4 ... - XVIII w.

2. P[eter] Petersen oraz P. P. - XVIII/XIX w.

3. Bibliotheca Suchtelen. - ekslibris, XIX w.

Opr.: tekt., półskórek, papier marmurkowy, tłocz. złocone na grzb., obc. nakrapiane czerwono i niebiesko - XVIII w.

3.10.3.38/2

38. Ogier, Charles: Ephemerides, sive iter Danicum, Svecicum, Polonicum... Lutetiae Parisiorum, P. Le Petit, 1656; $8^{\circ}$.

Prow.:

1. Kongl. Secreteraren J.D. Flintenbergs Lån-Bibliothek - ekslibris, XVIII/XIX w.

2. Bibliotheca Suchtelen. - ekslibris, XIX w.

3. Biblioteka Główna w Warszawie - pieczęć, XIX w.

Opr.: tekt., półskórek, papier marmurkowy - XVIII/XIX w.

Sd.712.430

39. Petrejus, Petrus: Forsta [- siette] Book påthenna Muskowiterska Crönika om the Storfurster och Regenter... aff Petro Petreio. - Stockholm, Ign. Meurer, $1614-15 ; 4^{\circ}$.

Prow.:

1. 194. E[ric ?] Bergstrom Ups[ala] 1821.

2. Biblioteka Instytutu Historycznego Uniwersytetu Warszawskiego - pieczęć, XX w.

Nieliczne marginalia - XVII w.

Opr.: tekt., półskórek, papier marmurkowy (wytarty), obc. nakrapiane niebiesko - XVIII w.

28.20.3.1120

40. Plutarchus: [Vitae parallelae, Germ.] Ankunfft, Leben und versen... warhaffte Historien... - Colmar: Gedr. durch Barpt. Grieninger, 1547 (1541); $2^{\circ}$. Prow:

1. Mauritz Sture Graff zu Steg[e]holm zum Vaestervik mp - XVI w.

2. Schuanto Sture - XVI w.

Opr.: deska, skóra cielęca, tłocz. ślepe, klamra, resztki 2-giej - XVI w.

Sd.602.948 
41. [Psalmboken]: Den Swenska psalm-boken... år 1695 ofwersedd och nodtorfteligen forbåttrad. - Stockholm, J. P. Lindh, 1797; $12^{\circ}$. Prow.:

1. Susanna De Mare yödd Brantberg död den 18 Desember 1837 - czy prow.?

2. Własność Biblioteki Zboru Ewangelicko-Reformowanego w Warszawie - pieczęć, XIX w.

Opr.: tekt., skóra cielęca, tłocz. ślepe, ślady klamer - XVIII/XIX w., zniszcz. 28.20.4.4429 adl.

42. [Psaltaren]: K. Davidz Psaltare medh små summarier... - Stockholm, O. Olofsson, 1619; $4^{\circ}$.

Prow.:

1. I A R - tłocz. oraz Jahan [!] Arntzij [?] Reijmer mpp - XVII w.

2. Nalepka sygn. na grzb. 19/A/B 1 .

Opr.: tekt., skóra cielęca, tłocz. złocone, obc. złocone - XVII w.

Obce XVIII- $4^{\circ}-16^{\circ}-1576$

43. Ramus, Petrus: Arithmeticae libri duo, geometriae septem et viginti... Francofurti: apud Andr. Wecheli haer., Claud. Marnium et Io. Aubrium, $1599 ; 4^{\circ}$.

Prow.:

1. DA[niel] TH[eodori] F[abrivilensis] 1599 - tłocz. oraz Daniel Theodori Fabrivillensis, Svecus possessor legitimus Lipsiae A[nno] Christogonias MDIC.

2. Negat modo Petrus Doberus Arosiensis - zamazane, XVII w.

3. Viro non minus polito quam erudito D[omi]no Abrahamo Kempe S[acr] ae R[egi]ae M[aiesta]tis super Wermelandia constituto mathematico practico, amico haud vulgari, hunc Librum mathematicum amicitiae pariter ac memoriae caussa dono dedi, in villa mea Boo in Carlskoga, 22 Novembris Anni 1634, Petrus Dobertus Aros[iensis] m[anu] p[ro] pria.

4. Abrahamus Kempe mpp - XVII w.

5. 1822 goda Podarena G[ubernskim]' Kol[ležekim'] Sekretarem'K[arolom'] Etterom' - w jęz. ros.

6. [Imperatorskaja Biblioteka - St. Petersburg] - sygn., XIX w.

7. [Akademia Medyko-Chirurgiczna w Warszawie ?] - sygn., XIX w.

Liczne marginalia i glosy po łac., rzadziej po niem. i szwedzku, 3-4 rąk, w tym ręką 1. właściciela, XVI-XVII w.; rysunki, podkreślenia; zapisy matematyczne i historyczne (m.in. o wynalezieniu druku przez J. Gutenberga, daty życia M. Lutra, itp.).

Opr.: tekt., skóra świńska, tłocz. ślepe, ślady wiązań - XVI w.

Sd.604.2090 
44. Réaumur, René Antoine Ferchault de: Memoires pour servir a l'histoire des insects... - Paris, Imprimerie Royale, 1734-42; $4^{\circ}$.

Prow.:

1. Schönherr - ekslibris, XVIII w.

2. Carl G[ustaw] Tessin - XVIII w.

3. Bibliotheca Suchtelen. - ekslibris, XIX w.

Opr.: tekt., skóra cielęca, grzb. i krawędzie złocone, dublura, wyklejki z papieru marmurkowego - XVIII w.

3.6.2.12/2

45. Richardson, Jacob: Hallandia antiqua et hodierna... - Stockholm, L. Salvius, $1752-53 ; 2^{\circ}$.

Prow.:

1. Joh. Erici Noréen Stockholmiensis 1765.

2. Biblioteka General'nago Štaba - ekslibris, XIX w.

Opr.: tekt., półskórek, papier marmurkowy, tłocz. złocone - XIX w.

9.15.3.7-8/3

46. Saint-Germain, Claude Louis de: Memoires... - Amsterdam, M.M. Rey, $1780 ; 8^{\circ}$.

Prow:

1. M[atthias] Benzelstierna - ekslibris, XVIII w.

2. Biblioteka General'nago Štaba - ekslibris, nalepka sygn.(1553) na grzb., XIX w.

3. Akcesja BUW: 1863/647.

Opr.: tekt., skóra cielęca marmoryzowana, tłocz. złocone na grzb. - XVIII w.

9.2.10.6/1

47. Sansovino, Francesco: Historia universale dell'origine guerre et imperio de Turchi... - Venetia, S. Combi, 1654; $4^{\circ}$.

Prow:

1. Eric Oxenstierna mp. - XVII w.

2. Biblioteka General'nago Štaba - ekslibris, nalepka sygn. (6362) na grzb., XIX w.

3. Akcesja BUW: 1863/659.

Opr.: tekt., skóra cielęca marmoryzowana, tłocz. złocone na grzb. - XVII w.

9.2.4.2/2

48. Scheffer, Johann: Memorabilium Sueticae gentis exemplorum liber singularis. - Hamburgi, Holmiae, G. Liebezeit, N. Spieringius, 1687; $8^{\circ}$.

Prow.:

1. Michäel Hermonius d[ie] 20 octob[ris] 1706. 
2. Biblioteka General'nago Štaba - ekslibris, nalepka sygn. (5302) na grzb., XIX w.

Opr.: tekt., pergamin - XVII w.

9.7.10.28/1

49. Snorre, Sturlasson: Heims Kringla... Nordländske Konunga Sagor sive Historiae Regnum septentrionalium... - Stockholmiae, Literis Wankiwianis, $1697 ; 2^{\circ}$.

Prow:

1. Sebastian Grave - XVIII w.

2. J. N. Lindahl-XVIII w.

3. Biblioteka General'nago Štaba - ekslibris, nalepka sygn. (5490) na grzb., XIX w.

Zapis bibliograficzny [?], dat. 1764 .

Opr.: tekt., skóra cielęca marmoryzowana - XVIII w.

9.15.3.12/3

50. Sollis y Ribadeneira, Antonio de: Histoire de la conquete du Mexique ou de Prow.:

la nouvelle Espagne... - La Haye, A. Moetjens, 1692; $8^{\circ}$.

1. N G, tłocz. - XVIII w.

2. zapis wycięty 9 thaler [?].

2. Carl Fredrik Mennander - ekslibris, XVIII w.

3. Biblioteka General'nago Štaba - ekslibris, nalepka sygn. (5654) na grzb., XIX w.

Opr.: tekt., skóra cielęca, tłocz. złocone na grzb. - XVII/XVIII w.

8.7.2.20/1

51. Strelow, Hans Nielsson: Cronica Guthilandorum... - Kiobinghaffn, M. Martzan, $1633 ; 4^{\circ}$.

Prow.:

1. Johan Birth excerpsit - na końcu notatki bibliograficznej, XVII/XVIII w.

2. Eric Michael Fant Upsala 1774.

3. Biblioteka General'nago Štaba - ekslibris, nalepka sygn. (7277) na grzb., XIX w.

Opr.: karton niebieski - XIX w.

9.3.11.28/1

52. Terserus, Johannes Elai: Förklaring öfwer catechismum eller de sex war christlige läras hufwudstycken... - Abo, P. Hansson, 1663; $12^{\circ}$.

Def.: brak k. tytułowej, uzupełn. rps.

Prow.:

1. Jåc[ob] Ståhle im opt på auctioni Åbo d. 27 Sept. 1797 oraz Jåcob Ståhle. 
2. Bibliothecae Suchtelen - pieczęć heraldyczna, XVIII/XIX w. Opr.: tekt., pergamin - XVII w.

5.5.13.27/1

53. Wassenberg, Eberhard: Der Teutsche Florus... - Dantzigk, A. Hünefeld, $1643 ; 12^{\circ}$.

Prow.:

$\mathrm{C}$ [ristina] R[egina] S[veciae] - superekslibris, XVII w.

Opr.: tekt., pergamin, tłocz. złocone - XVII w.

Sd.711.637 